\title{
Critical Success Factors for Vietnamese Software Companies: A Framework for Investigation
}

\author{
Duy Anh Vu \\ Maastricht school of management, Vietnam \\ Email: vu_anh_duy@yahoo.com \\ Quynh Hoa Bui \\ Maastricht school of management, Vietnam \\ Email: quynhsaga@gmail.com \\ Trung Quoc Pham \\ HoChiMinh City University of Technology, Vietnam \\ Email: pqtrung@gmail.com
}

Accepted: July 17, 2012 Published: August 28, 2012

Doi:10.5296/jsr.v3i2.2307

URL: http://dx.doi.org/10.5296/jsr.v3i2.2307

\begin{abstract}
Promoting information technology (IT) industry and identifying the critical success factors contributing to the success of IT companies are of special concerns for the Vietnamese government. This conceptual framework is formed to explore "The key determinants of success of software companies in Vietnam". A number of factors have been identified from reviewing of relevant literature for an investigation. They are: vision, operation capacity, founder personality, finance, and employee ability. This coming research will use quantitative research method, conducted from surveying of 120 managers of 55 software companies in Vietnam. However, due to the nature of this conceptual paper, the results will not be analyzed and discussed in the paper until the ending of this project in August, 2012. The research will contribute to better understanding of existing literature related to factors contributing to success of software companies in Vietnam.
\end{abstract}

Keywords: Software, IT, Success Factors, SDI

\section{Introduction}

In the late 1990s, Vietnamese government put the top considerations on software 
development industry (SDI) through policies, investments and supports to software companies running in Vietnam (Thesaigontimes, 2011). The goal of these actions is to transform Vietnam into a strong Information Technology nation in general and SDI in particular. Therefore, for the last 10 years, information and communication technology (ICT) has been developing rapidly.

White book (2011) states that in the period 2001-2009, average revenue growth of Vietnamese information technology (IT) is $20 \%-25 \%$ per year. By the end of 2010, the hardware industry revenue was 5.6 US\$ billion, the telecommunications services revenue was 9.4 US\$ billion, revenue of the software industry and digital content industry is quite small with 2.0 US\$ billion, bringing whole IT industry \& telecom revenue (17 US\$ billion) is 19 times higher than that in 2000. Therefore, IT Industry has been becoming an important economic sector to contribute for GDP growth increases year to year.

However, as compared to other countries in area such as Thailand, Philippines, China, and India, the overall picture of Vietnamese SDI is still rather gloomy. In 2010, the revenue of SDI Vietnam is 2.0 US\$ billion while revenues of Thailand, Philippines, China and India are 2.5 US\$ billion (Boi.go.th, 2011), 6.0 US\$ billion, 197 US\$ billion (Hwang, 2011), and about 75 US\$ billion (Khurana, 2011) respectively.

Although SDI Vietnam had the preparations very early, it is still the young industry, too dependent on outsourcing, and lack of high competition. The Vietnamese software industry hasn't reached its potential or people's expectations (Tuoitrenews, 2011).

With the booming information technology (IT) and expected growth of SDI, the questions to be advanced from that are: 'what impact to success of software companies in Vietnam?' and 'how can Vietnamese government promote software industry?'.

Over the past few years, there have been many studies and articles about SDI in the world and regional countries, but not much research has been done about this subject matter in Vietnam. Therefore, this paper aims at constructing a conceptual model for exploring "The key determinants of success of software companies in Vietnam", which is requisition for Vietnamese SDI as well as strategic support of Vietnam government.

\section{Literature Review}

\subsection{Software Companies}

Software companies are organizations whose business is software. Software is programs and the instruction codes making electronic components. Software is developed or engineered in a complicated process that consists of many steps such as: requirement specification, detailed designs, modules construction and debug, integration and system test, etc. Recently business of software is diversified with fields such as operation systems, applications, packed software, and games, etc. According to Hughes \& Cotterell (2006), software projects are 
different from traditional projects as their characteristics are invisibility, complexity, conformity and flexibility.

\subsection{Success}

Recently the common defined success is the completion of anything intended or the reaching of goal. Dellmour (2006) concludes that success is achievement of the company's objectives and the opposite of failure. In order to measure success of companies, prior researchers show many factors such as profit, turnover, market share, customer satisfaction, employee satisfaction, and owner satisfaction, etc. However, employee satisfaction is seen as one of most important factors to detect a successful business (Kehoe \& Kevin, 1994, and Surepayroll, 2012), because employee satisfaction can affect directly to customer satisfaction in working environment (Alicia, Lori \& S.Douglass, 2011) and simultaneous it is also essential drivers of quality and productivity (Matzler \& Renzl, 2006). Therefore, success in this research is achieving the defined goal and emphasized on employee satisfaction.

\subsection{The Vietnamese critical success factors for IT firms}

Over the last decades, although software industry always mentions as strategic economic development of many nations, the detail models of factors impacting to success of Vietnamese software companies are not much empirically addressed. Therefore, the conceptual model and hypotheses of this research are proposed by extending and integrating conceptual models from prior researches and factors related with success and growth of software companies in Vietnam. Furthermore, the 'contextual factor' concerning employee ability will be added to the model as it is a most challengeable factor for success of Vietnamese software companies. Consequently, the proposed factors from prior researches and circumstance of Vietnam are: vision, operation capacity, founder personality, finance, and employee ability. Each factor will be addressed in more details.

Vision

Kantabutra\& Avery (2010) state that vision is seen as a core component for any organization to stay competitive and to thrive. Although previous researchers emphasize on important of vision, no one know exactly what vision looks like (Avery 2004).Vision should be defined by each individual leader (Baetz \& Bart, 1996) to strengthen business strategy. Vision is known as a starting point of any organizational transformation process and a guide for a wide range of business activities over a long period of time.

Visions can make a significant impact on customer satisfaction and employee satisfaction, which is the bottom line of any business. Besides, visions must be desirable, inspiring, concise, clear, future-oriented, stable, and challenging.

\subsection{Operation Capacity}


In the research of identifying why firms fail or survive in the volatile software industry; Li, Shang and Slaughter (2010) suggest that operation capacity is the strongest positive impact to survival of software companies. They also argue that higher operation capability increases software firm survival more than higher marketing and research \& development capabilities.

Firms must be able to cost-effectively produce commercially viable software, implying that operation capacity is another distinctive capability of software firms (Hayes \& Upton, 1998). Operation capacity here is firm's ability to use resources cost effectively such as employee, cost of goods sold, capital expenditure, etc. Indeed, operational capabilities can be surprisingly robust in keeping competitive advantage (Hayes \& Upton, 1998; Oliver, 1997). Stronger operation capabilities help a firm get the rent or income from innovative products.

\subsection{Founder Personality}

Founder Personality is one of the key factors affecting to success or fail of technologies companies as argued by many scholars (Van de ven, Hudson \& Schroeder, 1984; Sabisch, Helmut, 1999; Dellmour, 2006). Founder personality is always necessary on startup success and company stage of development (Van de ven, Hudson \& Schroeder, 1984; Dellmour, 2006). In small businesses, the entrepreneur must often act as the central brain (Van de ven, Hudson \& Schroeder, 1984). However, the bigger the company, and the more managers and other employees there are, the more significance shifts from the founder away towards the team (Dellmour, 2006).Therefore, personal characteristics of founder can distinguish between later stage and early firms. Competence, confidence, imagination and commitment are seen as core characteristics of founder (Van de ven, Hudson \& Schroeder, 1984).

\subsection{Finance}

Finance is an important factor to support company in investing and keeping its business. With analyzed results of 220 'start-up' Information and Communication Technology (ICT), Lasch, Roy \&Yami (2007) state that finance has a significant on the success of young ICT firms. The financial investment of IT companies is much lower than that of other companies (Dellmour, 2006). However, according to statistics of Vietnamese government (Baodientuchinhphu, 2011), by 2011, 98\% of enterprises in Vietnam were small and medium; which often are small sizes about capital, labor forces, and finance. Thus finance is a vital factor for the growth of Vietnamese companies. Finance is a rather broad area but finance here means primarily the ability to acquire initial and subsequent Capital. Especially failed companies state that their failure was from inability to acquire further Capital (Dellmour, 2006).

\subsection{Employee ability}

In Vietnam, human capital is still potential problems: the education needs to change much more as its quality decreases so much (Le, chairman - TMA solution); English is often poor; 


\section{Macrothink}

Journal of Sociological Research

ISSN 1948-5468

2012, Vol. 3, No. 2

among 270 schools (universities and colleges) about training IT, there are only 100 schools which have students take part in national programming exams. Besides, Vietnam is excess the low-skill people but lack of high-skill people (Prof. Hoang - Chancellor of a Vietnamese IT University).Therefore, employee ability emphasizes on abilities of employees such as: operation, self-training, language skills and managerial skills, etc. In another way, it can be said that the strength of employee can derive from strong universities, polytechnics, and vocation schools. Thus, the recent success cases in this area - India, Israel, and Ireland, all benefited from a strong national emphasis on advanced technical education that date back at least one or two generations (Hai, 2001). Barr \& Tessler (1998) show that skill can be learned in a few months or a few years while talent is the ability to see complex system problems. English language ability has been critical to this point in national software success. Finally, management skills are needed in order to manage successful firms. Therefore, it is essential to include 'employee ability' in the model for testing the possible impact of this factor on company's success.

Having addressed a numbers of key factors examined by different studies, it is essential for us to assume that such distinct findings from many international scholars will provide us a strong theoretical background to construct our own conceptual framework for investigation. The next section will discuss the framework of the study and hypothesis

\section{Proposed Model And Hypothesis}

From prior research, literature review and the context of Vietnamese economic, political and social environments, the research assumes that the success of software companies in Vietnam is measured by employee satisfaction and influenced by five factors: vision, operation capacity, founder personality, finance, and employee ability. 


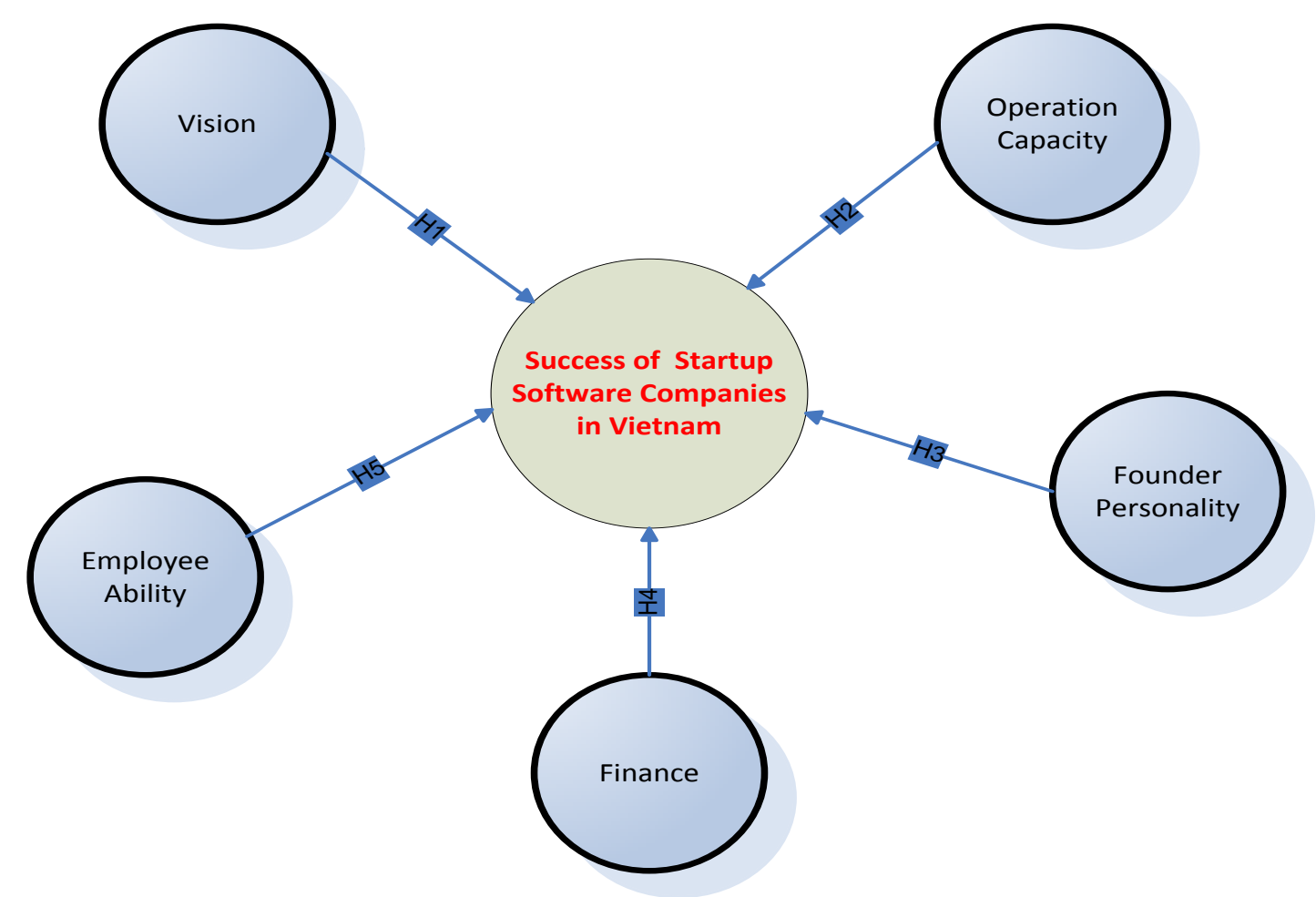

Figure 1: Conceptual model; constructed from relevant literature review

H1: There is a positive impact of Vision on success of software companies in Vietnam H2: There is a positive impact of Operation capacity on success of software companies in Vietnam

H3: There is a positive impact of Founder personality on success of software companies in Vietnam

H4: There is a positive impact of Finance on success of software companies in Vietnam H4: There is a positive impact of Employee ability on success of software companies in Vietnam

\section{Research Design \& Method}

\subsection{Research Process}




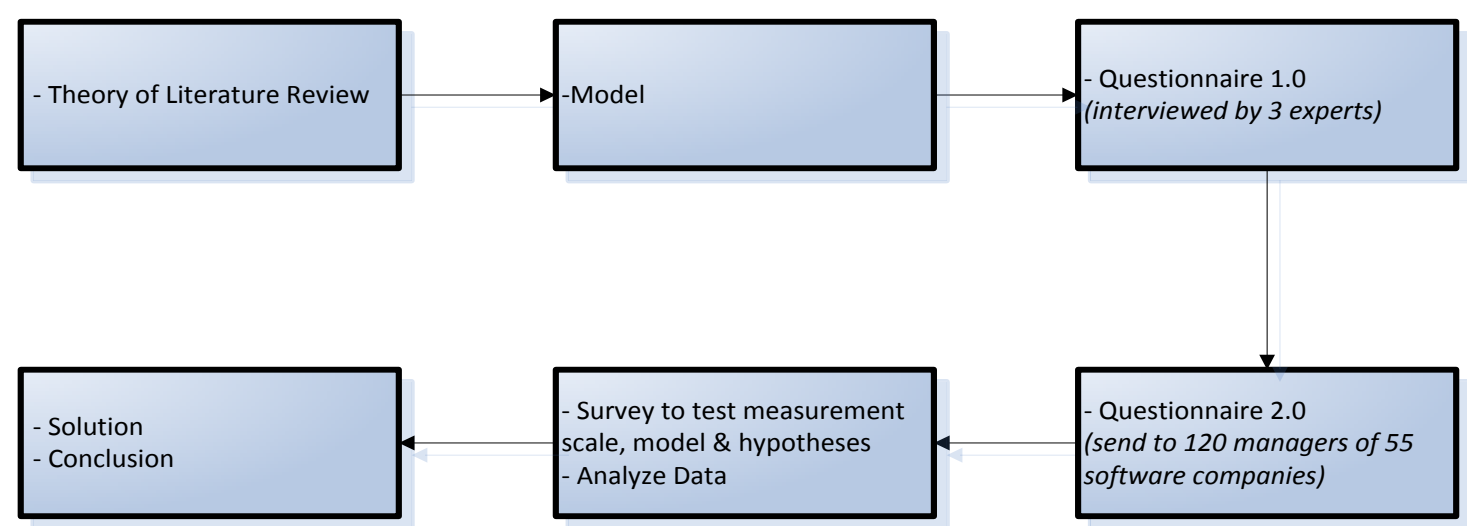

Figure 2: Research procedure; Source: Constructed by authors

The research focuses on managers working in software companies in Ho Chi Minh City and Hanoi. Most the selected software companies will be local companies. The reason why we chose Hanoi and Hochiminh is they are perhaps the two most concentrated IT cities in Vietnam.

\subsection{Research design}

The questionnaire is based on the five-point likert scale. This research will be a quantitative research, conducted from 120 managers of 55 software companies in Vietnam. Those companies are select randomly from public business directory. Based on the conceptual model, questionnaire are developed and sent to 3 IT strategic experts, who have deep knowledge of IT and strategic management in software development industry in Vietnam for their invaluable recommendations. Their suggestion will help to construct the most suitable questionnaires for covering in the survey. This necessary step will help to ensure the questionnaires are comprehensible. Therefore, the survey can provide the most useful information for data analysis.

\section{Conclusion}

In Vietnam, despite being supported by Government such as tax immunity, invested infrastructure and training, etc., $28 \%$ of total software companies get break-even after 3-4 years and $41 \%$ of total software companies profit from 10\% - 30\% (tapchibcvt, 2006). It could be said that this practice did not encourage for Vietnamese software enterprises in particular and Vietnamese SDI in general.

Therefore, a question raised here from this paper is to seek for the key determinants of success of software companies in Vietnam. Moreover, the answer of this question will bring a suitable solution for both industrial and governmental organizations in supporting the development of software industry. The results of research may also help the entrepreneur to have a better preparation for investing and running in software industry. At the same time, this model could be a useful instrument to provide information to support the software 


\section{Macrothink}

Journal of Sociological Research

ISSN 1948-5468

2012, Vol. 3, No. 2

industry. This is an ongoing project and due to the nature of this research paper as a conceptual paper only; the researcher is unable to go further to provide and discuss any information concerning data analysis, discussion and research findings. Perhaps, this is the limitation of the conceptual paper. Additionally, future qualitative in-depth interview in some carefully selected case studies may be required for explaining the quantitative research findings.

\section{References}

Avery, G.C. (2004). Understanding Leadership.Sage Publications.

Alicia, A.G., Lori, S.G.\& S.Douglass, P., (2011). .Employee Satisfaction, Responsiveness, and Customer Satisfaction: Linkages and Boundary Conditions. Academy of Management Annual Meeting Proceedings, pp. 1-6.

Baetz, M.C. \& Bart, C.K. (1996).Developing mission statements which work. Long Range Planning,Vol. 29 No. 4, pp. 524-31.

Boi.go.th (2011).Thailand Software Industry. Retrieved March 12, 2012, from http://www.boi.go.th/index.php?page=opp_software

Baodientuchinhphu (2011). Doanh nghiệp nhỏ và vìa: bước tiến lớn (en: "Small and medium enterprises: big progress"). Retrieved on March, 12, 2012 from http://baodientu.chinhphu.vn/Home/Doanh-nghiep-nho-va-vua-buoc-tien-lon/20111/58354.v $g p$

Barr, A. \&Tessler, S. (1998).Treasuring IT Talent. Intelligence Magazine.

Barr, A.\& Tessler, S. (1998). How Will the Software Talent Shortage End?American Programmer.(Also reprinted in Dr. Dobb's Journal.)

Dellmour, B. (2006): Critical success factors it-start-up companies. Thesis published from http://www.grin.com

Hai, H. (2001), Analyze the development of the Vietnamese software industry. Thesis, retrieved on March 24, 2011, from Website: http://www.mde.edu.vn/haiha.asp

Hayes, R.\& D. Upton. (1998). Operations-based strategy. California Management Rev. 40(4) pp. 8-25.

Hughes, B. \&Cotterell, M. (2006).Software Project Management, Fourth Edition. London: McGraw-Hill, pp. 356. 


\section{Ml Macrothink}

Journal of Sociological Research

ISSN 1948-5468

2012, Vol. 3, No. 2

Hwang, A.(2010). China software industry sees 2010 total revenues up $31.3 \%$ on year. Retrieved March 14, 2012, from http://www.cn-c114.net/579/a580828.html

Kantabutra, S. and Avery, G.C. (2010).The power of Vision: statements that resonate. Journal of Business Strategy, Vol. 31, No. 1 2010, pp. 37-45.

Kehoe \& Kevin, R. (1994). The measure of success. American Nurseryman, pp.3, 73.

Oliver, C. (1997). Sustainable competitive advantage: Combining institutional and resource-based views. Strategic Management J. 18(9) 697-713.

Lasch, F., Roy, L.F. and Yami, F. (2007). Critical growth factors of ICT start-ups. Management Decision, Vol. 45, No.1, pp. 62-75.

Li, S., Shang, J., and Slaughter, A.S. (2010). Why do software companies fail? Information Systems Research, Vol.21, No.3, pp. 631-654.

Matzler, K. \&Renzl, B. (2006).The Relationship between Interpersonal Trust, Employee Satisfaction, and Employee Loyalty. Total Quality Management \& Business Excellence, pp. 1261-1271.

Sabisch\& Helmut (1999): Management technologieorientierter Unternehmensgründungen. (En: Management of technology oriented start-ups). Schäffer-PoeschelVerlag

Surepayroll (2012).Five Ways to Measure Success in Your Small Business. Retrieved March 12, 2012, from http://www.surepayroll.com/articles/small-business/how-to-measure-success-of-small-busine ss.asp,

Tapchibcvt (2006).Công nghiệp phần mềm Việt Nam - 5 năm nhìn lại. (En: Vietnam Software Industry - look back after 5 years). Retrieved March 12, 2012, from http://www.tapchibcvt.gov.vn/News/PrintView.aspx?ID=16362

Thesaigontimes (2011).Lận đận công nghiệp phần mềm. (En: Unsuccessfulness of Software Industry). $\quad$ Retrieved March 13, 2012, from http://www.thesaigontimes.vn/Home/congnghe/toancanh/51265/Lan-dan-cong-nghiep-phan$\underline{\text { mem.html }}$

Tuoitrenews (2011).Software industry still leaves much to be desired. Retrieved March 12, 2012 , from http://tuoitrenews.vn/cmlink/tuoitrenews/business/software-industry-still-leaves-much-to-bedesired-1.27232 


\section{Macrothink}

Journal of Sociological Research

ISSN 1948-5468

2012, Vol. 3, No. 2

Van de ven, H.A., Hudson, R., and Schroeder, M.D. (1984).Designing new business startups. Journal of Management, Vol. 10, No.1, pp. 87-104.

White Book (2011).Vietnam Information and Communication Technology. Information and communication publishing house. Retrieved on March 12, 2012 from http://mic.gov.vn/Attach\%20file/sachtrang/sachtrang2011.pdf 